原著

\title{
咀嚼・嚥下機能維持・改善プログラムに用いる 『噛みごたえのある固形食物』の選定のための官能試験
}

\author{
河村敦子，堤 雅恵，永田千鶴，野垣 宏，米村礼子11 \\ 山口大学大学院医学系研究科 地域·老年看護学 宇部市南小串 1 丁目 $1-1$ （ ₹755-8505） \\ 宇部リハビリテーション病院 看護部 ${ }^{11}$ ＼cjkstart宇部市西岐波229-3（テ755-0151）
}

Key words：固形食物，噛みごたえ，唾液分泌，咀嚼，官能試験

和 文 抄 録

【目的】現在高齢化率は $28.1 \% て ゙ ，$ 肺炎はわが国の 死因の第 5 位である．高齢者の肺炎による死亡は増 加し,その多くは誤嚥に起因すると報告されている. 本研究の目的は, 地域の高齢者が日常的に取り組め るような『噛みごたえのある固形食物』を用いた新 たな咀嚼・嶼下機能維持・改善プログラムを開発す るための前段階として，官能試験法を用いて『䛧み ごたえのある固形食物』を選定することである.

【方法】地域在住の高齢者を対象に, 同一の日に 5 つの食品（チューイングキャンディ・ガム・グミ・ 昆布・するめ) について, 掑食に要する時間, 摂食 前後の唾液分泌量を計測し, 官能試験を実施した. 【結果】研究対象者は20名（男性 7 名・女性 13 名） で, 平均年齢74.5 5.1 歳であった. 実験室の環境は, 平均気温 $24.5 \pm 0.8^{\circ} \mathrm{C}$, 平均湿度 $56.3 \pm 8.2 \%$ あっった。 口に含んでからなくなるまでに要する平均時間は, 5 食品間で有意な差 $(p<.001)$ を示し, 長く時間 を要した方から，するめ225.3 \pm 109.8 秒，ガム $205.6 \pm 57.1$ 秒, 昆布 $114.1 \pm 40.6$ 秒, チューイングキ ヤンディ $111.8 \pm 38.1$ 秒, グミ $100.3 \pm 43.4$ 秒であった. また, 唾液分泌量が食品を摂取した後に一番増加し た食品は，昆布（摂取前 $26.5 \pm 2.7 \% \rightarrow$ 摂取後 $27.9 \pm$ $2.2 \%, p=.091)$ であった。官能試験を総合的に評 価した結果，口に含んだときの硬さ，おいしさ， 20

令和 2 年 5 月 20 日受理
回噛んだときのうま味と噛みごたえが上位の評価に あり, さらに食べやすさやにおいの強さが他の食品 とほとんど差がなく, 口腔内への負担感が少なかっ た食品は昆布であった。

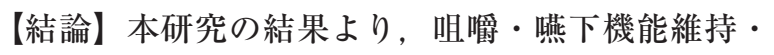
改善のプログラムの訓練として, 継続して幅広い高 齢者層が摂取するのに最も適した『噛み応えのある 固形食物』として, 昆布を選択した.

\section{はじめに}

現在高齢化率は $28.1 \% て ゙ ，$ 肺炎はわが国の死因の 第 5 位である ${ }^{1)}$. 肺炎患者の約 7 割が75歳以上の高 齢者で, 高齢者の肺炎は䛊嚥に起因するものが多い といわれている ${ }^{2}$. 先行研究では, 肺炎で入院した 70 歳以上の高歯者の $80.1 \%$ \% , 誤嚥性肺炎であった と報告されている ${ }^{3)}$. 高齢者では, 嬹下能力の低下 （反射の遲延，唾液の分泌の減少，喉頭位置の低下） がみられる ${ }^{4)}$. Ibayashiら5) は, 健常な高龄者54名 に対して, 口腔機能訓練プログラムのランダム化介 入試験を実施し, 噛む力, 嬩下能力, 唾液流速が有 意に改善したことを証明した。また菊谷ら ${ }^{6)}$ は, 介 護老人福祉施設入所者を対象に, 機能的口腔ケア訓 練を実施した結果，最大舌圧の上昇を認めた。これ らの研究結果より, 口腔機能訓練の揟食嚥下機能向 上への効果が示唆された。 また, Kawanishiら ${ }^{7)}$ 脳梗塞モデル動物研究において, 硬性食餌は学習・ 記憶障害を回復させるが, 軟性食餌, 特に液体食餌 
はそれを有意に残存させることを報告している。こ のことから，現在摂食嚥下訓練食はゼリーゃとろみ をつけた軟食（やわらかい食物）が多く用いられて いるものの，噛みごたえのある固形食物を用いた訓 練を行えば，咀嚼能力の改善や唾液分泌の増加など の摄食嬹下機能の向上だけではなく, 高齢者の肥満 予防, 脳血流の増加や認知機能を改善する可能性が ある。

本研究の目的は，地域の高齢者が日常的に取り組 めるような『噛みごたえのある固形食物』を用いた 新たな咀嚼・嚥下機能維持・改善プログラムを開発 するための前段階として，官能試験を行い『噛みご たえのある固形食物』を選定することである.

官能試験とは，人の感覚（視覚，味覚，嗅覚，聴 覚, 触覚) を利用して評価対象物の特性の強さや好 ましさの程度などを測定・評価することで，機器に よる測定が困難なものでも測定・評価できる手法と して世界的に用いられている8，9).

\section{研究方法}

\section{1. 研究デザイン：官能評価法を用いた質問紙調査 研究および観察研究}

本研究では，『噛みごたえのある固形食物』をチ ューイングキャンディ, ガム, グミ, 昆布, するめ の 5 種類から選択することにした。これらの食品は, 何度も咀嚼する行為を伴う噛みごたえのある固形食 物であり，毎日毎食前に手軽に摂取でき，経済的に
も家計の負担とならず，そして高血圧や糖尿病のリ スクがある高齢者の身体に負担が少ないという理由 で選択した．5つの食品の成分は，表 1 に示した。 5 食品の形態や質量はそれぞれ異なるが，1回の摂 取量を 1 粒・1 枚・ 1 千切りというように，およそ 1 回に摂取する分量を目安に，官能試験で摂取する 量を決定した。

\section{2. 研究対象者}

地域在住の高齢者が集まる自治会活動の場や地域 のふれあいセンターに出向き, 研究対象者を広く募 った. 地域在住の高齢者に対して, 研究同意説明文 書を用いて説明を行った後，文書による同意が得ら れた人を研究対象者とした。研究対象者は嘹好的お よび口腔の機能的にも，チューイングキャンディ, ガム，グミ，昆布，するめを食べることができる人 で，自分の感覚や感想を表現できる人とした．除外 基準として, 腎機能障害, 糖尿病で内服あるいはイ ンスリン注射をしている人や認知症の症状がある人 を除外した，また，飲み込みにくさがある，含嗽が できないなどの㯖下機能障害の症状がある人，外れ そうな差し歯や歯の詰め物がある人，あるいは義歯 が不適合な人も除外した。ささらに顎関節症の既往が ある人，頚部に疾患がある人，味覚の低下を自覚し ている人も除外した.

\section{3. 研究方法}

本研究では, 官能試験を行い $5 つ の$ 食品の中から 『噛みごたえのある固形食物』を選定していくが, 人の感覚を用いてデー夕を得る官能試験において

表 15 食品の成分表

\begin{tabular}{|c|c|c|c|c|c|c|}
\hline \multicolumn{2}{|r|}{ 商品名 } & $\begin{array}{c}\text { チューイング } \\
\text { キャンディ } \\
\text { (桃味) }\end{array}$ & $\begin{array}{c}\text { チューイング } \\
\text { ガム }\end{array}$ & $\begin{array}{c}\text { ハード系グミ } \\
\text { キャンディ } \\
\text { (ソーダ味) }\end{array}$ & $\begin{array}{l}\text { 味付け } \\
\text { 昆布 }\end{array}$ & $\begin{array}{c}\text { 焼きする } \\
\text { め }\end{array}$ \\
\hline \multirow{6}{*}{$\begin{array}{l}1 \\
\text { 食 } \\
\text { 分 } \\
\text { の }\end{array}$} & 重量 & $4.6 \mathrm{~g}$ & $4.5 \mathrm{~g}$ & $5.0 \mathrm{~g}$ & 約 $0.4 \mathrm{~g}$ & 約 $2.5 \mathrm{~g}$ \\
\hline & エネルギー & $19.0 \mathrm{kcal}$ & $8.3 \mathrm{kcal}$ & $7.5 \mathrm{kcal}$ & $1.0 \mathrm{kcal}$ & $7.9 \mathrm{kcal}$ \\
\hline & 蛋白質 & $0.07 \mathrm{~g}$ & $0 \mathrm{~g}$ & $0.20 \mathrm{~g}$ & $0.10 \mathrm{~g}$ & $0.17 \mathrm{~g}$ \\
\hline & 脂質 & $0.360 \mathrm{~g}$ & $0 \mathrm{~g}$ & $0.007 \mathrm{~g}$ & $0.002 \mathrm{~g}$ & $0.120 \mathrm{~g}$ \\
\hline & 炭水化物 & $3.8 \mathrm{~g}$ & $2.1 \mathrm{~g}$ & $1.8 \mathrm{~g}$ & - & $0.005 \mathrm{~g}$ \\
\hline & 食塩相当 & $0 \mathrm{~g}$ & $0 \mathrm{~g}$ & $0.003 \mathrm{~g}$ & $0.026 \mathrm{~g}$ & $0 \mathrm{~g}$ \\
\hline & 原材料名 & $\begin{array}{l}\text { 水飴、砂糖、 } \\
\text { 植物油脂、ゼラ } \\
\text { チン、桃ピューレ、レ、 } \\
\text { 酸味、料、乳剂、 } \\
\text { 香料、色素 }\end{array}$ & $\begin{array}{l}\text { 砂糖、ブドウ糖、 } \\
\text { パラチノース、エ } \\
\text { リストール、桑葉 } \\
\text { 抽出液、ガム } \\
\text { ベース、酸味料、 } \\
\text { 香料、軟化剂、 } \\
\text { 甘味料、色素、 } \\
\text { チャ抽出液 }\end{array}$ & $\begin{array}{l}\text { 水飴、砂糖、 } \\
\text { ゼラチン、植物油 } \\
\text { 脂、還元ハハラチ } \\
\text { ノース/ソルビトー } \\
\text { ル、酸味料、ゲル } \\
\text { 化剂、香料、着 } \\
\text { 色料、光沢剂、 } \\
\text { 甘味料 }\end{array}$ & 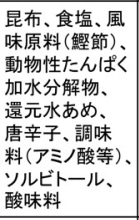 & するめ \\
\hline & 形態 & $\begin{array}{l}1.0 \mathrm{~cm} \times 1.3 \mathrm{~cm} \\
\times 2.7 \mathrm{~cm} \text { の直 } \\
\text { 方体 }\end{array}$ & $\begin{array}{l}2.0 \mathrm{~cm} \times 7.5 \mathrm{~cm} \\
\text { 厚さ約 } 0.1 \mathrm{~cm}\end{array}$ & $\begin{array}{l}\text { 約 } 1.4 \mathrm{~cm} \text { の立 } \\
\text { 方体 }\end{array}$ & $\begin{array}{l}\text { 約 } 1.0 \mathrm{~cm} \\
\times 5.5 \mathrm{~cm}\end{array}$ & $\begin{array}{l}\text { 約 } 0.6 \mathrm{~cm} \\
\times 8.0 \mathrm{~cm}\end{array}$ \\
\hline
\end{tabular}


は，再現性を確保することが重要である。そこで, 評価に影響を及ぼす要因（実験条件）をそろえ，研 究対象者が官能試験に集中しやすいように，実験室 の「臭気」「個室化」「室温」「湿度」「音」に関して 環境調整を行った。
官能試験は，唾液分泌の影響要因となる臭気の影 響をできるだけ取り除くために，ドラフトチャンバ 一（局所排気装置）が設置してある感染制御実験室 および感染制御実験室前室を使用して行った。試験 前にドラフトチャンバーを作動させ，一度無臭の状

表 2 「噛みごたえのある固形食物」の官能試験 質問票

氏名:

性別（男性 · 女性）

年齢 (

歳)

お忙しいところご協力ありがとうございます。 回答用紙は1枚あります。

水を一飲んでから、テストをはじめてください。

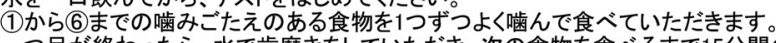

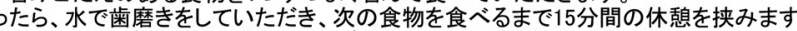

味や香りを評価するときは、感覚を集中するために鼻をつまみ、再度開けた状態で評価をしていただきますので、指示に従ってください。

<用語の説明>

官能評価とは、人の感覚(視覚、聴覚、味賞、臭覚、触覚)を使って対象物を評価することです。

歯肉とは、歯ぐきのことです。

口腔内粘膜とは、頪(ほっぺだの内側など、ロの中を覆う柔らかい組織のことです。

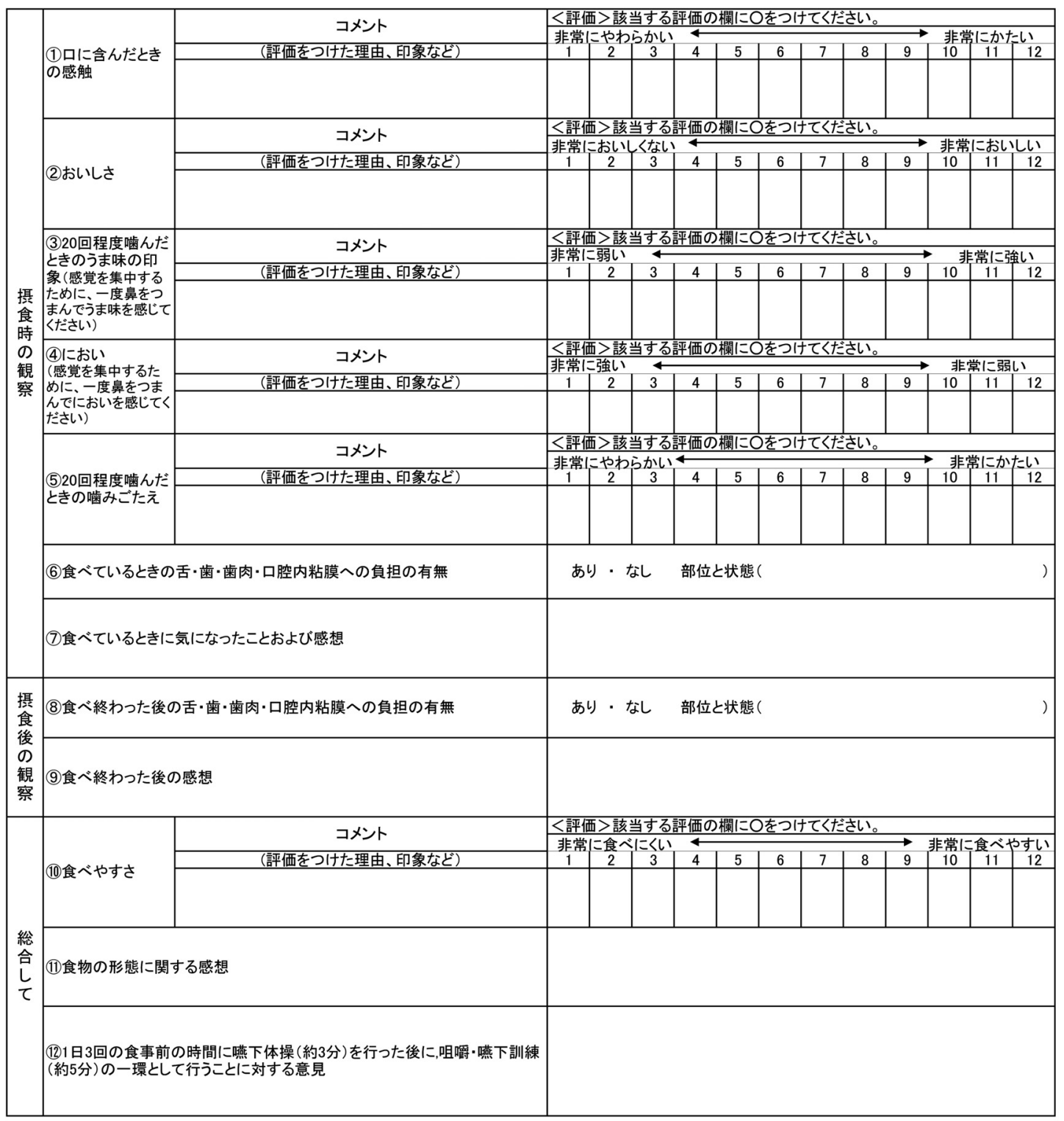


況にして行った，室内は活性炭などを用いて，でき る限り無臭に近い状態にした，各食物を摂取毎に， ドラフトチャンバーを作動させ, 無臭に近い状態に した後に，次の食品の試験を行った。

また，他の参加者からの影響要因を取り除くため に, スクリーンを使用し, 可能な限り個室化を行っ た．室温を $24 \pm 2{ }^{\circ} \mathrm{C}$ に調整し，湿度も可能な限り条 件が一定となるように $40 ６ 0 \%$ に調整した. そして， 外からの音刺激を遮るために, 扉や空を閉めて官能 試験を行った。また，ごみ箱は蓋付きごみ箱を感染 制御実験室前室に設置し, 前の食品の臭いが浮遊し ないように環境を整えた。研究対象者に対して, 実 験室への食品の持ち込みを禁止した。

さらに研究対象者には，正確な評価をしてもらう ために, 官能試験日には香水, ポマード, ローショ ンなど匂いのきついものの使用を禁止した．また女 性の参加者は, 当日口紅を付けてこないように説明 し，口紅を付けている場合は，クレンジングで落と した後に，試験を行った。喫煙者には，試験60分以 上前から喫煙しないようにした，試験前には，手指 を洗浄しておくが，匂いのきつい石喃を使用しない ようにした. 試験中に私語はしないように説明した。 試験中は，できる限り精神的ストレスを与えないよ うに配慮し, 安静に座位をとらせて行った。

官能試験は, 参加者に噛みごたえのある固形食物 の 1 ) チューイングキャンデイ，2）ガム，3）グ ミ，4）昆布，5）するめを順番に摂取してもらっ た，そして，各食物に関して食物を口に含んでから なくなるまでに要する時間（ガムは味がなくなるま での時間), 食物を口に含む前の棰液分泌量と食物 を摂取し口腔内からなくなった後の唾液分泌量の測 定や食物毎に官能試験の質問票の調查を行った，官 能試験の質問項目は12項目あり，1口にに含んだとき の感触，(2)おいしさ，(3)20回程度噛んだときのうま 味の印象，(4)に扔い，(5)20回程度噛んだときの噛み ごたえ, (6)食べているときの舌・歯・歯肉・只㬳内 粘膜への負担の有無, (7)食べているときに気になっ たことおよび感想，8食べ終わった後の舌・歯・歯 肉・控内粘膜への負担の有無, (9)食べ終わった後 の感想, (10食べやすさ, (11)食物の形態に関する感想, (12) 1 日 3 回の食事前の時間に嬹下体操（約 3 分）を 行った後に, 咀嚼・嚥下訓練（約 5 分）の一環とし て行うことに対する意見について調查した。 そして
(1)口に含んだときの感触であれば,「非常にやわら かい」を 1 として「非常にかたい」の12まで，12段 階で感触を評価するようにした。質問票の内容は, 表 2 に示した. 食べる順番によっても官能試験の結 果が変化する可能性があるため, 甘味と塩味が混在 した順番にならないように甘味から塩味の順番に撖 取し, 柔らかい食品から硬い食品へと摂取していく ようにした，さらに，前の検查で摂取した食品の影 響が次の試験に可能な限り残らないように, 各食物 掑取後に歯ブラシで歯磨き剤を用いずに水のみで歯 磨きをしてもらい，次の食物を摂取する間に WASH-OUT期間を15分間設けた.

唾液分泌量は, 口腔水分計ムーカス (ライフ社製, 埼玉県）を用いて測定した。ムーカスに関しては, 先行研究で口腔水分測定の有用性がすでに検証され ている ${ }^{10-12)}$.ムーカスは, 歯ブラシ様の形をした機 器で, 先端にセンサー部（7 mm四方）がある. 測 定ごとに絶縁体である専用カバーをセンサー部に装 着し，センサー部全体が密着するように舌先から $10 \mathrm{~mm}$ 奥の舌表面に当てる. 計測原理は, センサー が示す測定部位の静電容量から, 体脂肪計に用いら れるバイオインピーダンス (Bioelectrical Impedance Analysis）に対応する周波数を測定し, 得られたデー夕を水分量に変換して測定表示值を得 る. 2 回連続して測定し, 平均值をデータとした.

\section{4. 解析方法}

単純集計を行った後, 食物を口に含んでからなく なるまでに要する時間や官能試験の質問票の項目に ついては, 反復測定分散分析あるいはFriedman検 定を行い，5つの食品間の差の有無を見たのち CochranのQ検定やBonferroniの多重比較を行った。 自由回答のデータに関しては, 内容分析を行った。 食物の摂取前後の唾液分泌量の差は, Paired T検 定あるいはWilcoxonの符号付順位検定で分析を行 った。

\section{5. 倫理的配慮}

本研究は，世界医師会議のヘルシンキ宣言（2013 年フォルタレザ修正), 及び「人を対象とする医学 系研究に関する倫理指針」(平成 26 年文部科学省・ 厚生労働省告示第 3 号）に従って実施した。 山口大 学大学院医学系研究科保健学専攻医学系研究倫理審 查委員会で承認を得た後実施した（No.314）。研究 参加者に対して, 口頭および文書で研究に関する十 
分な説明を行い，文書による同意を得て行った？そ して, 研究に同意した後も途中で研究への参加を取 りやめたいときには，同意の撤回を行うことができ ることを説明した。 UMIN登録（UMIN000025383）。

\section{結果}

研究対象者は, 地域在住の高齢者 20 名 (男性 7 名, 女性 13 名), 平均年齢 $74.5 \pm 6.1$ 歳であった。研究対 象者は，同一の日に5つの食品の官能試験を実施し た. 研究期間は, 9 月 1 日から 10 月 1 日までの約 1 カ月間のうちの 4 日間で実施した. 実験室の環境は, 平均気温 $24.5 \pm 0.8^{\circ} \mathrm{C}$, 平均湿度 $56.3 \pm 8.2 \%$ であった。

\section{5 食品における摂取に要する時間の相違}

摂取に要する時間については，するめを最後まで 摂取出来ない人が 2 名あったため，すべての項目を 計測できた研究対象者18名のデー夕で解析を行っ た， 口に含んでからなくなるまでに要する平均時間
は，長く時間を要した方から，するめ $225.3 \pm 109.8$ 秒, ガム205.6 557.1 秒, 昆布 $114.1 \pm 40.6$ 秒, チュー イングキャンデイ $111.8 \pm 38.1$ 秒，グミ $100.3 \pm 43.4$ 秒 であった. Friedman検定を行い 5 つの食品の摂取 に要する時間を分析した結果，5つの食品で有意な 差（ $p<.001 ）$ が示された. 多重比較を行った結果 も含めて図 1 に示した。するめが, 昆布 $(p=.001)$, チューイングキャンディ（ $p=.009 ）$ やグミ $(p<.001)$ に比して摂取に要する時間が最も長か った. 次にガムが, 昆布 $(p=.002)$, チューイング キャンディ（ $p=.014 ）$ やグミ $(p=.001)$ に比して 摂取に要する時間が長かった.

\section{5 食品における摂取前後の唾液分泌量の相違}

摂取前後の唾液分泌量の変化については図 2 に示 した.すべての項目を計測できた研究対象者18名の データで解析を行った．各食品の摂取する前の唾液 分泌量の平均值と摄取した後の唾液分泌量の平均值 の差について，正規分布であったグミ・昆布・する

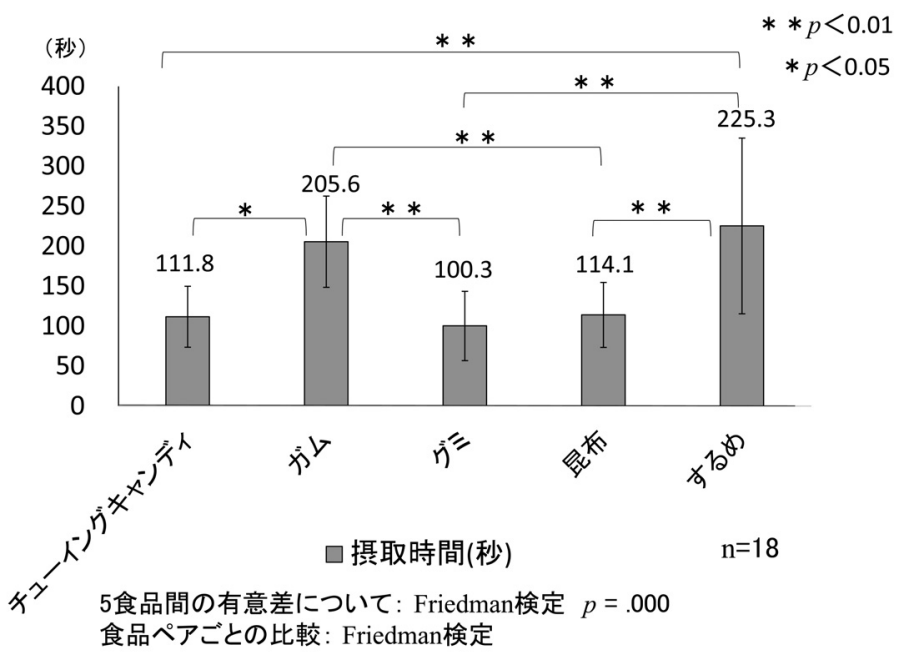

図 1 摂取に要する時間

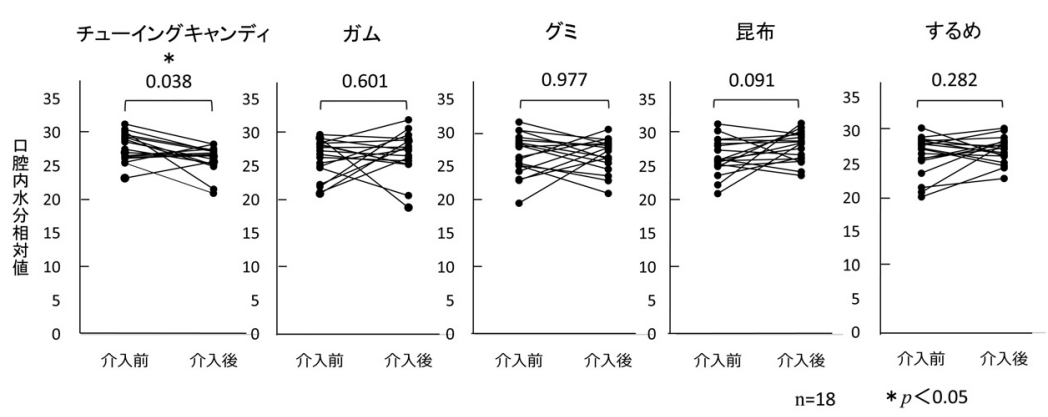

チューイングキャンディ・ガムの前後比較について:Wilcoxonの符号付順位検定 グミ・昆布・するめの前後比較について:Paired T検定

図2 摂取前後の唾液分泌量の変化 
めはPaired T検定で比較した。 そして，非正規分 布であったチューイングキャンディ・ガムは, Wilcoxonの符号付順位検定を用いて比較した。唾 液分泌量が食品を摂取した後に増加した食品は，昆 布（摂取前 $26.5 \pm 2.7 \rightarrow$ 摂取後 $27.9 \pm 2.2, \quad p=.091$ ), するめ（摄取前 $26.4 \pm 3.0 \rightarrow$ 摄取後 $27.2 \pm 2.0$, $p=.282)$ ， ガム（摂取前 $26.2 \pm 2.9 \rightarrow$ 摂取後 $26.9 \pm 3.2$,

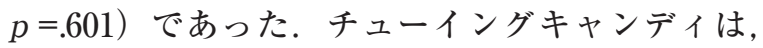
摂取の前後で有意差はあるものの, 唾液分泌量は減 少した（摂取前 $27.7 \pm 2.1 \rightarrow$ 摂取後 $26.1 \pm 2.0$, $p=.038)$. グミは，ほとんど同じ（罡取前 $26.8 \pm 3.1$

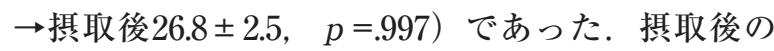
唾液分泌量の平均值が一番多かったのは，昆布であ った。

\section{3. 官能試験}

各食品を摂取中に12の官能試験の質問項目に関し て, 12段階で研究対象者20名の回答を得て分析した. 官能試験の結果に関する 5 食品の比較について, 表 3 に示した。

5 食品間の「口に含んだときの感触」を Friedman検定で分析した結果，5食品間で有意差 （ $p<.001 ）$ を認めた。口に含んだときの感触が一

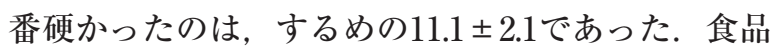
ペアごとの比較をFriedman検定で行った結果，す るめはチューイングキャンディ（ $p<.001 ）$ とガム $(p<.001)$ に対して有意差を認めた。次に昆布が $9.2 \pm 3.0$ で，ガム（ $p=.003 ） に$ に対して有意差を認め

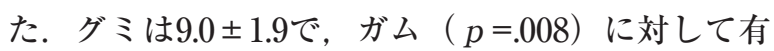
意差を認めた。次はチューイングキャンディで $5.8 \pm 2.6$, ガムは $5.3 \pm 1.9$ で一番軟らかかった.

次に「おいしさ」を反復測定分散分析した結果, 5 食品間に有意な差 $(p=.078)$ を認めなかった. それぞれの食品ごとの值は, 地域在住の高齢者がお いしさを感じた順から昆布9.6 1.7 ，チューイング キャンディ $8.6 \pm 2.7$ ， ガム $8.5 \pm 2.3 ，$ するめ $8.1 \pm 3.6$, グミ $7.8 \pm 2.3$ であった．食品ペアごとにBonferroni の多重比較を行った結果, 昆布はグミ $(p=.003)$ に対して有意差が認められた。

摂食時に「20回噛んだときのうま味」の印象を反 復測定分散分析で分析すると，5 食品間に有意な差 （ $p=.077 ）$ は認めなかった，地域在住の高齢者が一 番うま味を感じた順から，昆布 $9.0 \pm 1.8 ，$ するめ $8.6 \pm 2.3$, チューイングキャンディ $8.1 \pm 1.8, \quad ク ゙ ミ$ $8.0 \pm 2.2$, 最後はガム $7.4 \pm 2.3$ であった.

表 3 官能試験の結果に関する 5 食品の比較

\begin{tabular}{|c|c|c|c|c|c|c|c|}
\hline & $\begin{array}{l}\mathrm{a} \text { チューイン } \\
\text { グキャンディ }\end{array}$ & bガム & cグミ & d昆布 & eする女 & & $p$ \\
\hline (1)ロに含んだときの感触 & $5.8 \pm 2.6$ & $5.3 \pm 1.9$ & $9.0 \pm 1.9 \quad{ }^{* * *} p$ & $9.2 \pm 3.0 \quad$ 售 & $11.1 \pm 2.1$ & $a \cdot b_{p}^{* *}$ & .000 \\
\hline (2)おいしさ & $8.6 \pm 2.7$ & $8.5 \pm 2.3$ & $7.8 \pm 2.3$ & $9.6 \pm 1.7$ & $8.1 \pm 3.6$ & & .078 \\
\hline (3)20回噛んだときのうま味 & $8.1 \pm 1.8$ & $7.4 \pm 2.3$ & $8.0 \pm 2.2$ & $9.0 \pm 1.8$ & $8.6 \pm 2.3$ & & .077 \\
\hline (4)におい & $7.5 \pm 2.2$ & $6.5 \pm 2.7$ & $6.4 \pm 3.0$ & $7.0 \pm 2.8$ & $6.3 \pm 2.9$ & & .529 \\
\hline $\begin{array}{l}\text { (5)20回噛んだときの } \\
\text { 噛みごたえ }\end{array}$ & $4.4 \pm 2.9$ & $5.5 \pm 2.1$ & $6.4 \pm 2.7$ & $6.8 \pm 3.3$ & $9.2 \pm 2.1$ & $\begin{array}{c}* * * \\
\mathrm{a} \cdot \mathrm{b} p \\
c_{p}^{*}\end{array}$ & .000 \\
\hline $\begin{array}{l}\text { (6)食べているときの歯肉·ロ腔粘膜への鿓· } \\
\text { 担 }\end{array}$ & 20 & 5 & 15 & 25 & 53 & ${ }^{* * *}$ & .007 \\
\hline $\begin{array}{l}\text { (7)食べ終わった後の舌·歯· } \\
\text { 歯肉·口腔粘膜への負担 }\end{array}$ & 15 & 5 & 10 & 21 & 42 & $\mathrm{~b}^{*} p$ & .009 \\
\hline (8)食べやすさ & $9.1 \pm 2.1$ & $8.1 \pm 2.4 \quad e_{p}^{*} p$ & $7.6 \pm 2.5$ & $7.4 \pm 2.2$ & $4.8 \pm 3.2$ & & .000 \\
\hline
\end{tabular}

$\mathrm{n}=20 . p: 5$ 食品間の有意差. 5食品間の比較について, (1)·(5)はFriedman 検定を行い, (2)·(3)·(4)·(8)は反復測定分散分析を行った. (6)·(7) については, 負担があると答えた人が20名中何名いるかを\%で表し, CochranのQ検定を行つた. 食品のペアごとの比較について, (1)·(5) はFriedman 検定を行い, (2)·(3)-(4)·(8)はBonferroniの多重比較を行い, (6)·(7)はCochranのQ検定を行った. ${ }^{\mathrm{a} p}$ は, その食品のチューイング キャンディに対する有意差を示し, ${ }^{\mathrm{b}} p$ :ガム, ${ }^{\mathrm{c}} p$ :グミ, ${ }^{\mathrm{d}} p$ : 昆布, ${ }^{\mathrm{e}} p$ :するめに対する有意差を示す. ${ }^{* *}: p<0.01,{ }^{*}: p<0.05$. 
次に「におい」を反復測定分散分析で分析すると， 5 食品間に有意な差（ $p=.529 ）$ は認めなかった。 $5 つ の$ 食品に, 非常に強いにおいや非常に弱いにお いに偏ったものはなく，6から 7 の值であった．そ れぞれの值は, チューイングキャンデイ $7.5 \pm 2.2$, 昆布 $7.0 \pm 2.8$, ガム $6.5 \pm 2.7$, グミ $6.4 \pm 3.0$, するめ $6.3 \pm 2.9$ であった.

次に「20回噛んだときの噛みごたえ」については, Friedman検定を行った結果，5食品間に有意な差 $(p<.001)$ が認められた。するめの噛みごたえは 最も高く $9.2 \pm 2.1$ であり, 食品ぺアごとの比較にお いても, グミ $(p=.032)$, ガム $(p=.004)$, チュー イングキャンディ $(p<.001)$ に対して有意な差が 認められた。次に噛みごたえがあるのは, 昆布の $6.8 \pm 3.3$, その次はグミ $6.4 \pm 2.7$, ガム $5.5 \pm 2.1$ と続き, 最後がチューイングキャンディ $4.4 \pm 2.9$ であった.

食べているときの舌・歯・歯肉・ 口腔内粘膜への 負担の有無については, ありに丸を付けた人の人数 が 20 名中何名いるかを\%で表すようにした。 CochranのQ検定を行った結果，5食品間で有意な 差（ $p=.007 ）$ が認められた。するめ53\%，昆布 $25 \%$, チューイングキャンデイ $20 \%, \quad ク ゙ ミ 15 \%$, ガ ム $5 \%$ であった。するめを食品ぺアごとに比較した 結果, ガム（ $p=.004 ）$ に対して有意差を認めた.

食べ終わった後の舌・歯・歯肉・ 口腔内粘膜への 負担の有無についてCochranのQ検定を行った結 果, 5 食品間で有意な差 $(p=.009)$ を認めた。す るめ $42 \%$, 昆布 $21 \%$, チューイングキャンディ $15 \%$, グミ $10 \%$ ，ガム $5 \%$ であった. するめを食品ぺアご とに比較した結果, ガム $(p=.011)$ に対して有意 差を認めた。

「食べやすさ」を反復測定分散分析で分析すると， 5 食間に有意な差（ $p<.001 ）$ を認めた。食べやす かった順に，チューイングキャンディ $9.1 \pm 2.1$, ガ ム $8.1 \pm 2.4$, グミ $7.6 \pm 2.5$, 昆布 $7.4 \pm 2.2$, するめ $4.8 \pm 3.2$ であった，食品ぺアごとにBonferroniの多 重比較を行った結果, ガム $(p=.025)$ やチューイ ングキャンディ（ $p=.006 ）$ は，するめに対して有 意な差を認めた.

官能試験の自由記載の内容について, 食品別に内 容分析を行った。チューイングキャンディは，「甘 みと粘りがあり美味しい」，「ちょうど良い大きさで 食べやすい」という意見が多かった。しかし，「歯
にくっつく」, 「強い甘味が残り少し気持ち悪かっ た」,「入れ歯があるため不安」という意見もあった。 ガムは，歯にくっつきにくいガムを採用した。 「歯につかないので助かった」，「口に含んだときち ようど良い軟らかさ」,「唾液がよく出て顎が強化さ れている感じがある」，「義歯で強く噛めないので物 足りない」,「5分間噛むと顎のだるさを感じた」と いう意見があった。

グミは，「はじめは硬く感じたけれど，そのうち にどんどん美味しくなってきた」,「固体が小さくな っても噛む力を要した」.「20回噛むと軟らかくな る」,「弾力性が強く食べにくい」, 「硬くて食べにく い粘りがない」，「すぐに小さくなり飲み込みが早す ぎた感じ」，「角より丸い形の方が良い」という意見 があった。

昆布は，「昆布の甘みがあり後を引く美味しさ」, 「噛むとうま味が出てきた」,「喉の奥まで昆布のう ま味が残っている」,「最初はごわごわ感あり」,「口 腔内に傷がつかないか心配だったがじきに軟らかく なった」.「摂食後昆布の粘りが口の中に広がってい る」,「唾液の出方が多くなり訓練にも良い」,「咀嚼 力強化に良い食材だと思う」.「歯にくっつかないと もっと良い」,「形状に関して, 細長いので気をつけ て食べなければいけない」，「もう少し厚くて良い」, 「角が立ちすぎる，もう少し丸みを付けた方が良い」， $\lceil 2 \mathrm{~cm}$ 角くらいが食べやすい」という意見があった。 するめは,「先から少しずつ食べた」,「最初は硬 いが, 唾液が出てくるので軟らかくなる」,「硬さが 残っているので，軟らかくなるように歯で噛むよう にした」，「噛んでいくうちに美味しくなった」，「噛 みごたえは非常にある」，「人情味を感じる」，「義歯 なので強く噛めない」,「歯にかなり力を入れないと いけないので負担になった」,「なかなか噛めなくて 苦労した」,「するめを食べた後は, 顎がだるく何も 食べたくない」,「歯の状態が悪く, 噛み切るのは無 理のように思うので中止した」「噛む訓練には最高 の食材でないかと思う」,「奥歯の数が少ない人には, 飲み込むのが困難かも」，「するめのような食材は全 くだめ」という意見があった。形態に関して，「細 く割いてもう少し軟らかい方が良い」,「もう少し小 さい方が良い」，「半分の長さにすると噛みやすい」 という意見があった。

この 8 項目の結果に関して総合的に評価するため 
に，レーダーチャートを図 3 に示した，食べている ときや食べ終わった後の舌・歯・歯肉・只腔内粘膜 への負担感に関しては，負担感がないほど高い評価 となるように, 負担感がない人の全数に対する割合 を12段階で表現するように得点を算出した。

\section{考察}

本研究では, 咀嚼・噁下機能維持・改善プログラ ムに用いる『噛みごたえのある固形食物』を選定す るために官能試験を行った。嚥下機能の維持・改善 は, 嚥下体操や口腔体操を毎食前に実施し，囹食嬹 下に関わる口腔嚥下関連筋群を鍜えることで機能を 促進する，咀嚼機能の維持・改善は，『噛みごたえ のある固形食物』をよく噛んで咀嚼することで，機 能の維持・改善を図る. 人にとって噛む行為は, 咀 嚼過程の最も初期段階の重要な行為である。食物を 掑取するときの第 2 段階として，まず食物を口に取 り込んだ後, 上下の歯である程度の細かさに粉砕し， 舌と㚘頁の協調運動によって, 食物は繰り返し曰歯に のせられて, 臼歯は上下, 前後, 左右に動いて摩砕 する，圧縮力だけではなく，ずりの力（立方体から なる弾性体を考えたとき，物体の下面を固定し，上 面を下面に平行に変形させたとき，その物体の上下 の面には面に平行に反対向きに働く力）も加えて, 食物を細かく噛み砕き, 唾液が分泌され咀嚼過程は 進行する ${ }^{13}$. 粉砕された食品は舌により唾液と混ぜ
られ食塊となり,苝下に適切な物性となった食塊は, 咀嚼中であっても口腔から中咽頭へと移送されてい く ${ }^{14)}$. これらの咀嚼過程が適切に進行して, 嚥下機 能が安全に円滑にできるため, 噌む行為は非常に重 要な行為といえる。 小林は15), 食の文化に基づいた 歯応えと風味がある食物の十分な咀嚼は, 心身の成 長の促進, 脳の活性化とリラックス作用, 食物の発 がん物質の発がん性の減弱, 活性酸素の消去, 肥満 の抑制, 糖尿病治療効果の向上, 運動機能の向上, 骨粗鬆化の抑制, 脳の損傷や老化のリハビリテーシ ヨン効果などにつながることが示唆されたことを報 告している。 また, Kim H-Yら ${ }^{16)}$ は, 噌む能力の 改善は口腔衛生学関連の生活の質を向上させる可能 性があることを報告している，咀嚼・䀣下機能維持 改善プログラムに用いる『噛みごたえのある固形食 物』には，よく噛んで食べられるように，ある程度 の硬さがあり，噛むほどにうま味が味わえることが 重要である。また毎食前に継続して訓練が行えるよ うに, 高齢者に馿染みやすく, おいしい食品である ことと, 高血圧や糖尿病などの生活習慣病などに罹 患している高齢者に対しても負担のない食品が適し ている.

総合的に 5 食品を比較すると, 『噛みごたえのあ る固形食物』として「するめ」が最も硬さや噛みご たえはあった。 しかし, 義歯を装着しているあるい は歯が強勒ではない高齢者の中には，するめを最後 まで摂食することが困難で，途中で摂取をあきらめ

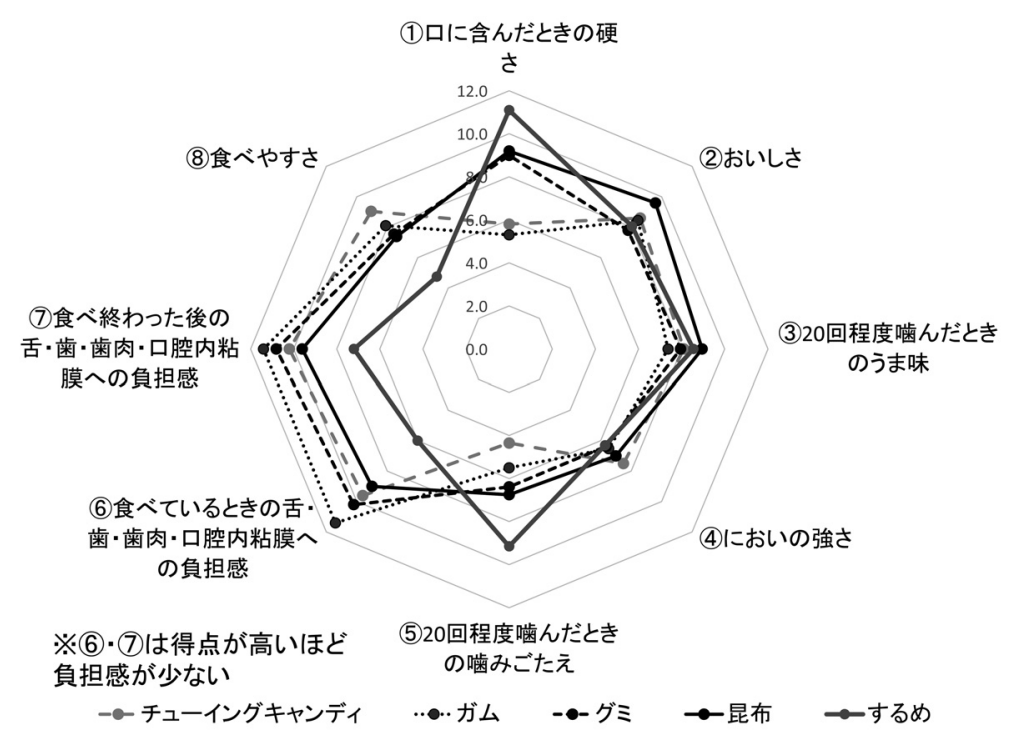

図3官能試験の総合評価 
る高齢者があった，幅広く高齢者層に，訓練の一環 として継続して摂取するのに最も適した食品は，口 に含んだときの硬さ，おいしさ，20回噛んだときの うま味，20回程度噛んだときの噛みごたえが上位の 評価にあり，さらに食べやすさやにおいの強さが他 の食品とあまり差がない, 口腔内への負担感が少な い昆布が一番適していると考えられる。

昆布の特徵として，1つは唾液の分泌促進効果が ある. Uneyamaら ${ }^{177}$ は, うま味の感覚は, 咀嚼や 食事の飲み込みに必要な唾液分泌, およびタンパク 質消化のための胃腸管を準備するための味覚反射を 誘発するため, 高齢者のQOLの向上に役立つ可能 性があることを示唆している，本試験において噛み ごたえがあると考えられる 5 食品の中で，食品の摂 取前後で唾液分泌量が最も増加した。 また佐藤ら ${ }^{18}$ は, 安静時唾液の分泌量は加齢によって減少し, 小 唾液腺唾液は安静時唾液としての役割が大きく, 口 腔乾燥感は総唾液分泌量よりも小唾液分泌量と関連 が深いこと, 基本 5 味の味覚刺激による小唾液腺唾 液分泌量の変化を計測した結果，うま味＞酸味＞塩 味=甘味=苦味であり,うま味刺激によって惹起さ れた唾液分泌反射は，他の味質刺激よりも長く持続 したことを報告している。ささらにドライマウス患者 への昆布煮出し液の頻回使用は，小唾液腺唾液分泌 量を増加させ, 口渇感および様々な併発症状を改善 させた， 口腔粘膜がただれている患者は，酸味によ り痛みを誘発するが，うま味は痛みを誘発しなかっ たと報告している ${ }^{19)}$.またAsakawaら 20, 21) は, コン ブ抽出液，ベタインおよびヒアルロン酸を含む洗口 剂を開発し，唾液分泌促進，保湿，洗浄の効果があ り, 特に高齢者において持続的な唾液分泌促進効果 を発揮することを報告している.

昆布のもう一つの特徵は，噛みごたえがある点で ある，今回の官能試験の結果, するめに次いで噌み ごたえがあった，神山ら ${ }^{222}$ は，咀嚼を多く必要とし， 甘味やカロリーが少なく, 食物繊維が主成分の昆布 を，噛みにくい食品として咀嚼機能食品に有望であ るとし, 昆布の咀嚼筋筋電図と咀嚼能力を調查して いる，粉砕能力が高い被験者は，昆布を短時間で噛 めるが，咬合面積が低い被験者は，昆布の嚥下まで に必要な筋活動量が高くなると報告している23. こ のことから, 残歯数の減少などで咬合力の低下して いる高齢者が噛みごたえのある昆布を咀嚼訓練に使
用した場合，筋活動量を高くする運動が口腔内で行 われる可能性がある.

また，昆布は昔から鰹節と同様にだし汁に使用さ れ，日本人にとっては子供の頃から慣れ親しんだ味 である。笹野24) は昆布から抽出されるうま味成分で あるグルタミン酸ナトリウムは, 口腔で味覚として 唾液分泌等の反射を引き起こすばかりでなく，消化 管では内臓感覚として消化吸収を調整することを報 告しており， 口脭機能を維持するうえで重要である ことを示した。ささらにTorii年) は，ラットの研究に おいてグルタミン酸ナトリウムの胃内注入は島皮 質, 辺縁系, 及び視床下部などのいくつかの脳領域 を活性化し，風味優先学習を誘導することを報告し ている。これらの結果は，グルタミン酸ナトリウム を多く含む昆布が唾液分泌を促進する効果だけでは なく, 高齢者の生体のホメオスターシスを調整し, 摂食䟞下を含む食行動の全般に良い影響をもたらす 可能性があることを示している.

\section{結 語}

官能試験の結果や先行研究の結果により, チュー イングキャンディ, グミ, ガム, 昆布, するめの中 から，本研究では昆布を『噛みごたえのある固形食 物』として咀嚼・嬩下機能維持・改善プログラムの 訓練食として最も適したものと考え選択した。

\section{謝 辞}

本研究にご協力いただきました研究対象者の皆様 に，心より感謝を申し上げます。

本研究は, 科研費・基盤研究C (課題番号16K12196) 及び公益財団法人浦上食品・食文化振興財団による 研究助成金（J28049）を用いて実施した。

なお，本稿すべての著者には，規定されたCOIは ない.

\section{引用文献}

1 ）厚生労働省. 平成30年度（2018）人口動態統計 月報年計（概数）の概況. 厚生労働省. https://www.mhlw.go.jp/toukei/saikin/hw/jin kou/geppo/nengai18/dl/kekka30-190626.pdf 
(参照2019-4-8)

2 ）厚生労働省. 資料2-1 2. 高齢化に伴い増加す る疾患への対応について. 第 2 回在宅医療及び 医 療・介護連携に関するWG. https://www. mhlw.go.jp/file/05-Shingikai-10801000Iseikyoku-Soumuka/0000135467.pdf（参照 2019-04-10)

3 ) Teramoto S, Fukuchi Y, Sasaki H, et al. High incidence of aspiration pneumonia in community- and hospital-acquired pneumonia in hospitalized patients : a multicenter, prospective study in Japan. J Am Geriatr Soc $2008 ; 56: 577-579$.

4 ) 藤谷順子. 高齢者の曣下障害. Jpn J Rehabil Med 2018 ; 55 : 234-241.

5 ) Ibayashi H, Fujino Y, Pham TM, et al. Intervention Study of Exercise Program for Oral Function in Healthy Elderly People. The Tohoku J Exp Med 2008 ; 215 : 237-245.

6 ) 菊谷 武, 田村文誉, 須田牧夫, 他. 機能的口 腔ケアが要介護高齢者の舌機能に与える効果. 老年歯学 $2005 ; 19: 300-306$.

7 ) Kawanishi K, Koshino H, Toyoshita Y, et al. Effect of Mastication on Functional Recoveries after Permanent Middle Cerebral Artery Occlusion in Rats. $J$ Stroke Cerebrovasc Dis $2010 ； 19$ : 398-403.

8 ) 家畜改良センター技術部技術第二課. II . 官能 評価，独立行政法人家畜改良センター，食肉の 理化学分析及び官能評価マニュアル，独立行政 法人家畜改良センター。 https://www.nlbc.go. $\mathrm{jp} /$ research/nikushitsuhyoka/shokunikumanual-2.pdf（参照2019-04-30)

9 ) 戸田 準. 日本食品工業学会誌にみる官能検査 の型と手法. 日本食品工業学会誌 $1994 ; 41$ : 218-223.

10) Takahashi F, Takahashi M, Toya S, et al. Clinical Usefulness of an Oral Moisture Checking Device (Mucus $\left.{ }^{\circledR}\right)$. Prosthodont Res Pract 2006 ; 5 : 214-218.

11) Mizuhashi F, Takahashi M, Mizuhashi R, et al. Influence of swallowing saliva repeatedly on oral moisture. J Prosthodont Res 2010 ;
$54: 128-132$.

12) Fukushima Y, Sano Y, Isozaki Y, et al. A pilot clinical evaluation of oral mucosal dryness in dehydrated patients using a moisturechecking device. Clin Exp Dent Res 2018 : 116-120.

13）中澤文子. 摂食から咀嚼・嶼下過程. 日本調理 科学会誌 $2006 ; 39: 185-193$.

14）山村健介。摂食・臙下の基礎. 化学と生物 $2013 ; 51: 302-309$.

15）小林義典. 咬合・咀嚼が創る健康長寿. 日補綴 会誌 $2011 ； 3: 189-219$.

16) Kim H-Y, Jang M-S, Chung C-P, et al. Chewing function impacts oral health-related quality of life among institutionalized and community-dwelling Korean elders. Community Dent Oral Epidemiol 2009 ; 37 : 468-476.

17) Uneyama H, Kawai M, Sekine-Hayakawa Y, et al. Contribution of umami taste substances in human salivation during meal. $J$ Med Invest 2009 ; 56 : 197-204.

18）佐藤しづ子, 笹野高嗣. 味覚唾液反射を応用し た新たな口腔乾燥治療。YAKUGAKU ZASSHI $2015 ; 135: 783-787$.

19）佐藤しづ子，笹野高嗣．ドライマウス治療に味 覚刺激を利用する。日薬理誌 $2015 ； 145 ：$ 288-292.

20) Asakawa R, Suzuki H, Yagi T, et al. Sialagogic effect of a New Mouthwash for Relieving Oral Dryness. Dent Health Curr Res 2017 ; 4 : 1-6.

21) Asakawa R, Suzuki H, Yagi T, et al. Pilot Study to Assess the Potential of New Moisturizing Agents for Oral Dryness. IJOMS $2017 ; 16: 25-30$.

22）神山かおる, 畠山英子, 小林知子, 他. おやつ 昆布の嚙みにくさと力学特性. Nippon Shokuhin Kagaku Kogaku Kaishi 2000 ; 47 : 822-827.

23）神山かおる, 畠山英子, 小林知子, 他. 昆布の 咀嚼筋筋電図と咀嚼能力. 日本咀嚼学会雑誌 $2000 ; 10$ : 41-49. 
24）笹野高嗣.「うま味」感覚の重要性について. 歯科学報 $2010 ； 110 ： 794-799$.

25) Torii K. Brain activation by the umami taste substance monosodium L-glutamate via gustatory and visceral signaling pathways, and its physiological significance due to homeostasis after a meal. J Oral Biosci 2012 ; 54 : 144-150.

\section{Assessment of a Sensory Evaluation Test to Select Suitable Chewy Solid Foods}

\author{
Atsuko KAWAMURA, Masae TSUTSUMI, \\ Chizuru NAGATA, Hiroshi NOGAKI and \\ Reiko YONEMURA ${ }^{11}$
}

Department of Community / Gerontological nursing, Yamaguchi University Graduate School of Medicine, 1-1-1 Minami Kogushi, Ube, Yamaguchi 755-8505, Japan 1 ) Department of Nursing, Ube Rehabilitation Hospital, 229-3 Nishikiwa, Ube, Yamaguchi 755-0151, Japan

\section{SUMMARY}

【Purpose】 The aim of this study was to use a sensory test to select "a chewy solid food" that could be incorporated into a new chewing and swallowing function maintenance and improvement program we developed for daily use by community-dwelling older Japanese.

【Method】 We measured the ingestion time and amount of pre- and post- ingestion salivary secretion on the same day for five foods (chewing candy, gum, gummi, kelp, dried cuttlefish), and performed a sensory test for each food.

【Result】 Among 20 participants, average intake time was significantly different $(p<.001)$ between the five foods. Dried cuttlefish required the longest time, but two participants could not eat it all. Kelp produced the largest increase in salivary secretion after intake. As a result of the sensory test, kelp had the highest evaluation for hardness, deliciousness, umami, chewiness, easy to consumption, odor, and feeling of less pressure on the oral cavity.

【Conclusion】Kelp was chosen as "a chewy solid food" that was most suitable for continuous consumption by a wide range of older Japanese. 